\title{
Do cognitive tasks during gait increase the risk of accidents with pedestrians? A study based on electromyographic parameters
}

\author{
Tarefas cognitivas durante a marcha aumentam o risco de acidentes \\ com pedestres? Um estudo baseado em parâmetros eletromiográficos
}

\author{
Camilla Zamfolini Hallal ${ }^{[a]}$, Marcelo Tavella Navega ${ }^{[b]}$, José Adolfo Menezes Garcia Silva ${ }^{[c]}$, \\ Deborah Hebling Spinoso $^{[\mathrm{b}]}$, Mary Hellen Morcelli ${ }^{[\mathrm{b}]}$, Luciano Fernandes Crozara ${ }^{[\mathrm{c}]}$, \\ Nise Ribeiro Marques ${ }^{[b]^{*}}$ \\ [a] Universidade Federal de Uberlândia (UFU), Uberlândia, MG, Brazil \\ [b] Universidade Estadual Paulista (UNESP), Marilia, SP, Brazil \\ [c] Universidade Estadual Paulista (UNESP), Rio Claro, SP, Brazil
}

\begin{abstract}
Introduction: Accidents involving pedestrians are responsible for many cases of serious injuries and deaths. Crossing streets safely requires complex planning and cognitive demand because it is necessary to perform more than one task at a time. Objective: The aim of this study was to identify electromyographic changes during gait in young subjects who performed the cognitive tasks concurrently. Methods: The study included 17 younger women aged between 18 and 25 years. Data collection was performed on a treadmill. The volunteers were instructed to walk in four different conditions: normal gait (NG), gait with dual easy task (DET), gait with dual hard task (DHT) and gait with dual mixed task (DMT). Results: Significant differences were found between the MN condition to the other conditions for all muscles and, during the NG, smaller values of muscle activation were found. Muscle co-contraction between muscles VM / BF showed a significant difference between the conditions of NG and DMT ( $p=0.04)$ and, during the NG, smaller values of co-contraction were observed. Conclusion: The data of this study permits to conclude that the competition between motor and cognitive resources significantly affects the levels of muscle activation and co-contraction during gait in young adult women. Thus, we conclude that the performance of dual cognitive tasks while driving can be considered a risk factor for safe driving.
\end{abstract}

Keywords: Gait. Falls. Electromyography.

\footnotetext{
* CZH: PhD, e-mail: camillazhallal@yahoo.com.br MTN: PhD, e-mail: marcelonavega@yahoo.com.br JAMGS: MS, e-mail: jose_megasi2@hotmail.com DHS: MS, e-mail: deborahebling@gmail.com MHM: PhD, e-mail: mmorcelli@yahoo.com.br LFC: PhD, e-mail: lucianocrozara@gmail.com NRM: PhD, e-mail: nisermarques@yahoo.com.br
} 
Resumo

Introdução: Os acidentes de trânsito envolvendo pedestres são responsáveis por muitos casos de lesões graves e óbitos. Atravessar a rua com segurança requer complexo planejamento e demanda cognitiva, pois é necessário realizar mais de uma tarefa ao mesmo tempo. Objetivo: $O$ objetivo do presente estudo foi identificar alterações eletromiográficas durante a marcha de indivíduos jovens realizada concomitantemente com tarefas cognitivas. Métodos: Participaram do estudo 17 jovens do sexo feminino com idade entre 18 e 25 anos. A coleta de dados foi realizada em esteira ergométrica onde os voluntários realizaram o teste de marcha compostos por quatro condições distintas: marcha normal (MN), marcha com dupla tarefa fácil (DTF), marcha com dupla tarefa difícil (DTD) e marcha com dupla tarefa mista (DTM). Resultados: Foram encontradas diferenças significativas entre a condição de MN para as demais condições para todos os músculos, sendo que durante a MN foram encontrados menores valores de ativação muscular. A co-contração muscular entre os músculos VM/ BF mostrou diferença significativa entre as condições de MN e DTM $(p=0,04)$, sendo que durante a MN foram observados menores valores de co-contração. Conclusão: Os dados do presente estudo, nos permitem concluir que a competição entre recursos motores e cognitivos afeta, significantemente, os níveis de ativação muscular e co-contração durante a marcha de mulheres adultas jovens. Assim, concluímos que a realização de duplas tarefas cognitivas durante a marcha pode ser considerada um fator de risco para o desempenho seguro da mesma, podendo ocasionar maior risco de acidentes aos pedestres.

Palavras-chave: Marcha. Quedas. Eletromiografia.

\section{Introduction}

Pedestrians represent the largest group of people using public roads (1). Traffic accidents involving pedestrians are responsible for many cases of severe lesions and deaths (2). According to the World Health Organization, lesions causes by traffic accidents are an increasing public health problem and one of the main causes of death in young adults between 15 and 44 years of age (3).

In Brazil, the number of fatal victims of traffic accidents reaches 38 thousand per year, with trampling representing $26.6 \%$ of traffic accidents, being responsible for approximately $46.9 \%$ of deaths (4). Accidents involving pedestrians mostly happen while crossing the street (1). The large number of accidents involving pedestrians entails high costs for the health systems. Traffic accidents represented a deficit of 5.3 billion reais for public funds (5). In 2010, the Unified Health System spent about 187 million reais for the hospitalization of 145,920 traffic accident victims (6).

Crossing the street safely requires complex planning and a high level of cognitive demand, as more than one task needs to be accomplished at the same time, such as paying attention to the signs and traffic, besides walking $(7,8)$. Accomplishing dual tasks while walking is a very common daily situation and a prerequisite for a functional life (9). The dual task is a frequently used method to assess gait, as it permits the division of a primary motor performance task, which is the main focus, and a secondary task, both executed at the same time (10). Studies appoint that, when the gait happens concomitantly with another cognitively demanding activity, the performance of both tasks can be negatively affected, as gait requires attention and high levels of cognitive resources for planning, monitoring and coordination $(11,12,13)$.

The high economic value associated with the social impact of accidents involving pedestrians gives rise to the implementation of accident prevention programs through intervention based on scientific evidence. Understanding how a situation of rapid decision making and gait can change biomechanical parameters and increase the risk of accidents is very relevant for the creation of public traffic education policies, for the review of signals and accident prevention strategies. Therefore, electromyographic assessment can provide detailed information on muscle activation and co-contraction and support the identification of atypical motor behaviors that can increase the risk for pedestrians.

Hence, the objective in this study was to identify electromyographic alterations during gait in young individuals when performed concomitantly with cognitive tasks. We raise the hypothesis that cognitive challenges during gait alter the muscle activation and co-contraction patterns, predisposing individuals to a greater accident risk.

\section{Methods}

The study participants were 17 young women between 18 and 25 years of age, college students who practiced physical exercise at least three times per week. Table 1 shows the subjects' characteristics. The exclusion criteria were the presence of pain, fracture 
or severe soft tissue lesion during the six months preceding the study, as well as a history of neurological, cardiovascular or respiratory problems. The volunteers who reported dizziness or discomfort during the tests were also excluded from the sample.

Approval for this study was obtained from the ethics committee at Universidade Estadual Julio de Mesquita Filho, Rio Claro Campus (process 69/2009) and all participants signed the free and informed consent form.

Table 1 - Characteristics of volunteers

\begin{tabular}{cc}
\hline \multicolumn{2}{c}{ Characteristics } \\
\hline Age (years) & $21.47( \pm 2.06)$ \\
Body mass $(\mathrm{Kg})$ & $60.68( \pm 5.93)$ \\
Height $(\mathrm{m})$ & $1.63( \pm 0.05)$ \\
Preferred speed $(\mathrm{m} / \mathrm{s})$ & $0.95( \pm 0.84)$ \\
\hline
\end{tabular}

Note: Kg: kilograms; m: meters; m/s: meters/second.

The data were collected on a treadmill (Millenium Supra IBRANMED ${ }^{\circledR}$ ) with the volunteers wearing a parachute safety belt to prevent falls during the tests. Before the start of the data collection, the participants became familiar with walking on a treadmill at their preferred speed (12).

After getting familiar, the gait tests started, consisting of four distinct gait conditions: normal gait (NG), gait with dual easy task (DET), gait with dual hard task (DHT) and gait with dual mixed task (DMT). The conditions were executed in random order through a simple draw for each volunteer. All conditions took place during three consecutive minutes, in line with the individually selected preferred speed during the familiarization period. In NG, the volunteers were asked to walk on the treadmill at their preferred speed. For the DET, the volunteers answered simple subtraction counts verbally (subtraction of one number), involving randomly chosen figures between 1 and 99, while walking on the treadmill at their preferred speed. During the DHT, the volunteers answered complex subtraction counts verbally (subtraction of seven number), involving figures between 1 and 99. For the DMT, the participants answered simple and complex subtraction counts verbally, involving randomly chosen figures between 1 and 99 (11).

To collect the electromyographic data, Myoresearch $\left(\right.$ Noraxon $\left.^{\circledR}\right) 16$ channel telemetry module with 12 Bit resolution and common rejection mode of $90 \mathrm{~dB}$ was used to collect biological signals, together with Myoresearch $\left(\right.$ Noraxon $\left.^{\circledR}\right)$ software. The electromyographic data were collected during all gait tests in all conditions proposed. $\mathrm{Ag} / \mathrm{AgCl}\left(\right.$ Meditrace $^{\circledR}$ ) surface electrodes were arranged in a bipolar configuration. Before placing the electrodes, trichotomy, fine abrasion and skin cleaning with alcohol were done to avoid possible interferences in the electromyographic signal, (14). The following muscles were assessed: rectus femoris (RF), vastus lateralis (VL), vastus medialis (VM), long head biceps femoris (BF), tibialis anterior (TA), gastrocnemius lateralis (GL) and soleus (SO). The reference electrode was placed on the right malleolus lateralis. The electrodes were placed in accordance with SENIAM standards (14).

To analyze the electromyographic data, ten consecutive cycles of gait were used to initiate the NG, DET, DHT and DMT conditions. The cycles were determined by recording at the same time as the electromyographic data collection. The start and end of the cycle were marked by the moment of the longest distance between the reflexive point of the right malleolus and the left metatarsus, during the touch of the right heel (15). That is the moment when the reflexive point of the right malleolus can be identified best due to the slowing down of the leg segment for the heel to touch the floor.

The electromyographic signals were collected using a $1000 \mathrm{~Hz}$ sampling frequency and processed through routines developed in a MatLab 7.0 ${ }^{\circledR}$ environment. After spectrum analysis, the use of a $20 \mathrm{~Hz}$ high-pass filter, $500 \mathrm{~Hz}$ low-pass, $60 \mathrm{~Hz}$ notch, with a gain of 2000 times. The data were rectified to create the linear envelope. The rectified data were interpolated at 501 points on each of the ten gait cycles in each condition to obtain the best data window for all cycles and subjects. Each subject's linear envelope values were standardized by the mean values of the normal gait condition for each muscle.

The co-contraction percentage was calculated by the muscle activation area referring to the linear envelope of the following muscles: RF and BF, VM and BF, VL and $\mathrm{BF}, \mathrm{TA}$ and GL, and TA and SO according to the equation below, as proposed in (16). In this equation, the percentage of muscle co-contraction corresponds to the common muscle activation area in the linear envelope of the agonist and antagonist muscles, multiplied by 2 and by 100 , divided by the agonist activation area added up to the antagonist activation area.

\section{$\%$ COCON $=2 \times$ common area $A \& B \times 100$ area $\mathrm{A}+\operatorname{area} \mathrm{B}$}

The statistical analyses were developed in the software PASW statistics $18.0^{\circledR}$. The normality of all variables was verified through the application of the Shapiro-Wilk test. To analyze the muscle activation data, Friedman's Anova and Dunns' Post hoc tests were used to compare the different gait conditions. Significance was set at $5 \%(\mathrm{p}<0.05)$. 


\section{Results}

Figure 1 shows the data on the muscle activation of RF, VM, VL, BF, TA, GL and SO, respectively, for the group of young people in the NG, DET, DHT and DMT conditions. Significant differences were found between the NG condition and the other conditions for all muscles. During the NG, low muscle activation scores were found. No significant differences $(p>0.05)$ were found between the muscle activation of VL to compare DET and DHT, and SO between DET and DMT. For all other comparisons, significant differences were found $(p<0.05)$.
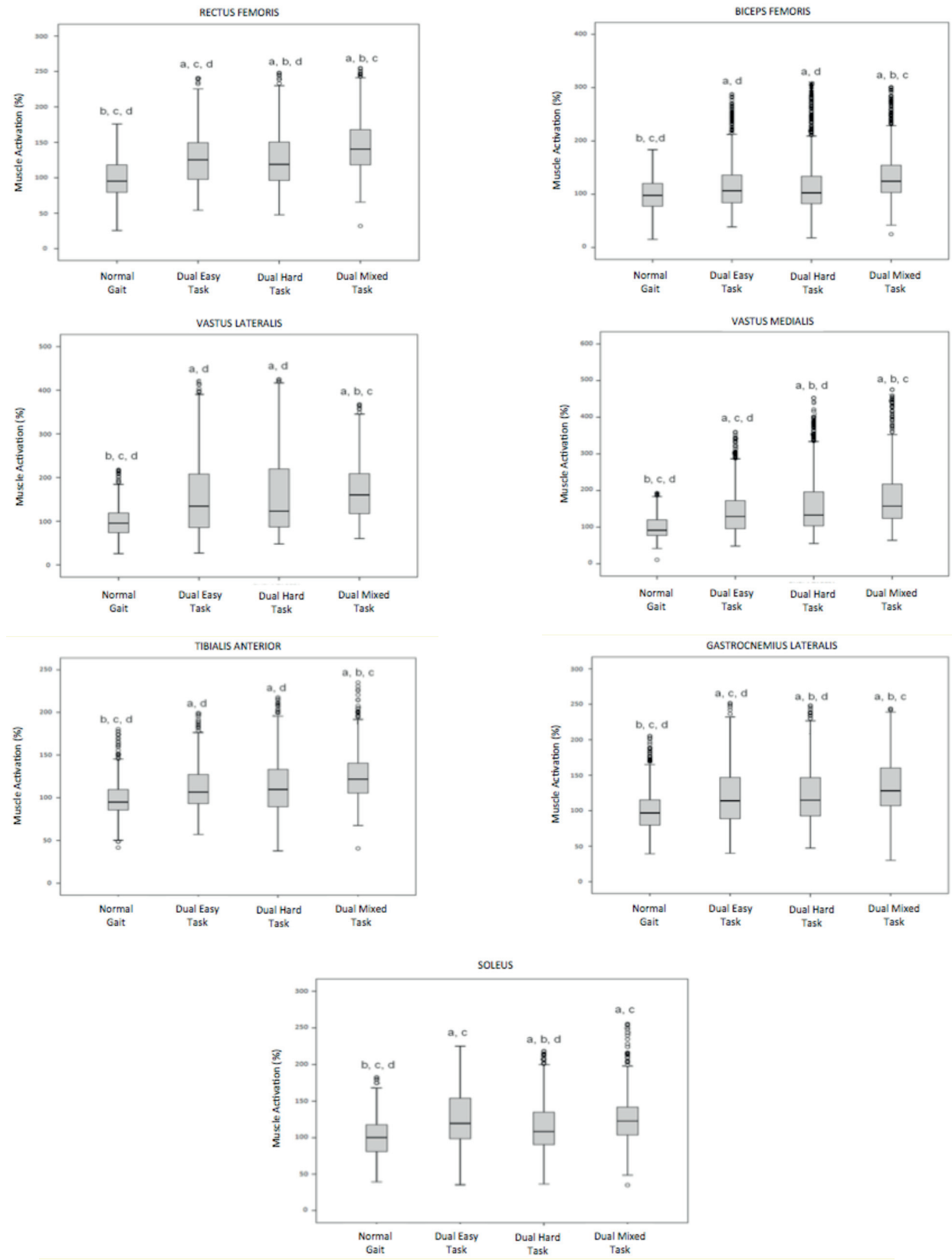

Figure $\mathbf{1}$ - Medians and quartiles of muscle activation of rectus femoris, biceps femoris, vastus lateralis, vastus medialis, medial, tibialis anterior, gastrocnemius lateralis and soleus for normal gait, gait with dual easy task, dual hard task and dual mixed task conditions.

Note: a: Significant difference with normal gait. b: Significant difference with dual easy task. c: Significant difference with dual difficult task. d: Significant difference with dual mixed task. 
Figure 2 represents the volunteers' performance concerning the co-contraction percentage for the different conditions they were submitted to during the tests. The muscle co-contraction between the VM/BF muscles showed a significant difference between the NG and DMT conditions ( $p=0.04)$. During the NG, low co-contraction coefficients were found. For the other muscles, no significant differences were found in the co-contraction levels among the different dual-task conditions imposed.
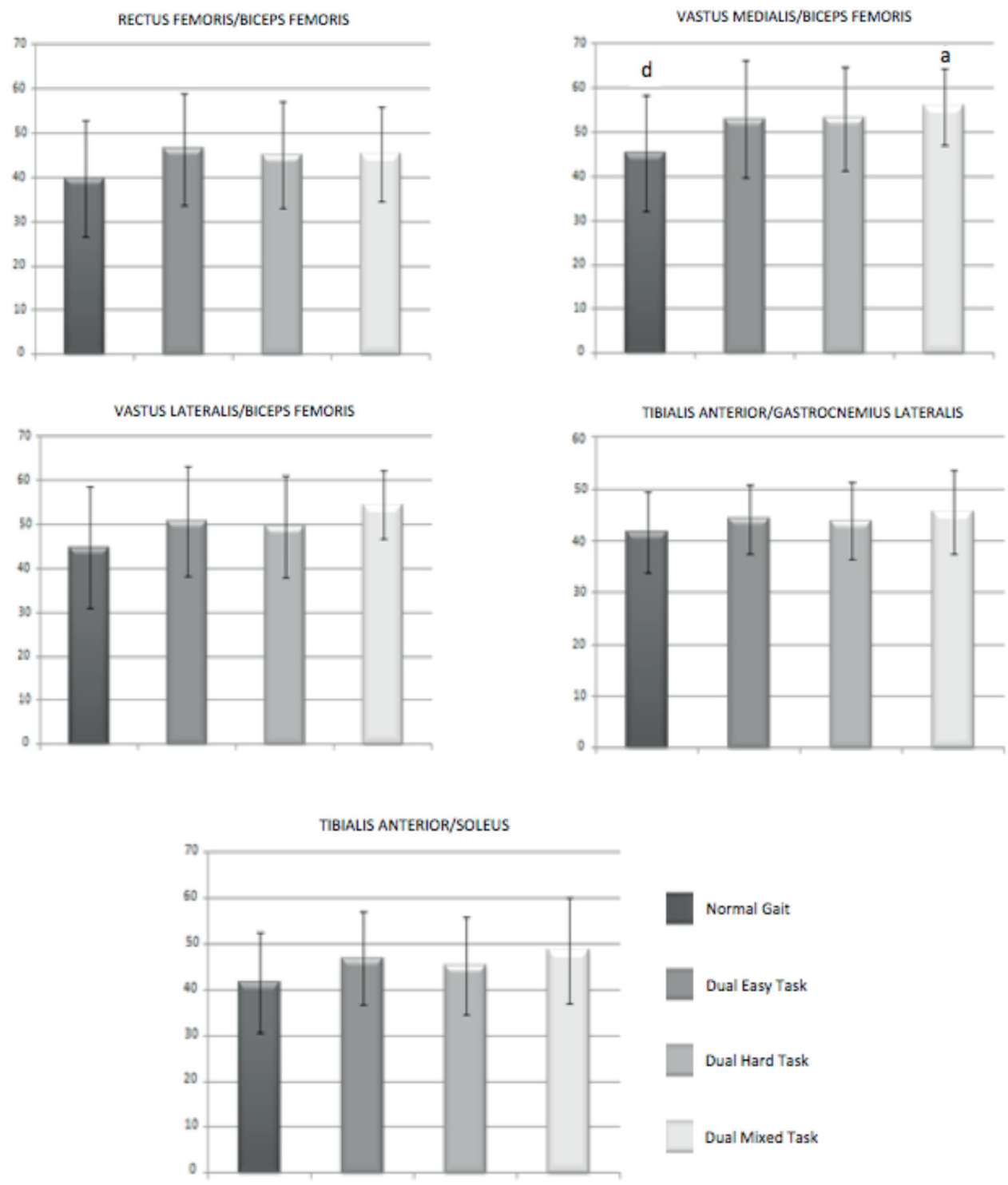

Figure 2 - Means and standard deviations for co-contraction percentage in different test phases between rectus femoris/ biceps femoris, vastus medialis/ biceps femoris, vastus lateralis/ biceps femoris, tibialis anterior/ gastrocnemius lateralis, and tibialis anterior/ soleus muscles.

Note: a: Significant difference with normal gait. d: Significant difference with gait with dual mixed task. TRAD: normal, dual easy task, dual difficult task, dual mixed task. 


\section{Discussion}

The execution of gait should not be considered an exclusively automatic act or a mere reflex, but a process that requires association between cognitive and muscle reactions to produce an appropriate action $(11,17,18)$. Thus, this study intended to identify electromyographic changes during the gait of young individuals, executed concomitantly with cognitive tasks that can predispose these individuals to a higher accident risk. These study results showed a lower muscle activation level during normal gait in relation to the dual-task conditions in all muscles assessed. Concerning the co-contraction percentage, an increase in co-contraction was observed between VM and BF in the dual mixed task condition when compared to the normal gait.

Maintaining the coordination and appropriate sequential muscle activation during gait is a fundamental mechanism to execute the preset trajectory, besides minimizing the energy consumption and improving the function (19). Adding cognitive tasks can alter the muscle activation pattern during gait due to the neural competition during cognitive processing. When two or more stimuli are happening almost at the same time, the processing time will be longer due to shared capacity limitations (20). Hence, the execution of an additional task while walking changes the gait(13). In this study, changes were found in the muscle activation patterns during gait in different cognitive demands. All muscles assessed presented differences in their activation level as a result of the different dual-task conditions. These variations can provoke errors in maintaining the gait parameters and cause inefficiency in maintaining the activity performed (21).

Abbud et al. (11) proposed the association between gait and the solution of mathematical expressions, identified competition for executive resources during their association, denigrating the execution of the motor task and the cognitive task, with a significant increase in mistaken response patterns and in the latent time for reactions while executing a dual hard task. These authors considered that the muscle responses indicated the distribution of neural resources to execute the activities proposed, raising the hypothesis that the increase in the cognitive demand leads to a reduction in the muscle responses associated with the motor tasks proposed.

Our results on the muscle activation profile while performing the dual task do not support the results presented by Abbud et al. (11) as, in our study, the muscle activation pattern increased during the association of the tasks. One probable explanation is that we propose gait on a treadmill. Despite the familiarization proto$\mathrm{col}$, this is not a daily task, predisposing the subjects to greater cognitive interferences (22).

Deviating neural resources that are intended for postural control can entail a reduction in postural stability and increased range of mass center oscillations $(23,24,25,26)$. In our study, increased co-contraction was found in the DMT gait condition between the VM and BF muscles when the dual task was implemented. Some authors $(12,26,27)$ observed that the increased co-contraction and performance during tasks associated with primary movement patterns can cause different reactions, according to the demand level of the tasks proposed. The increased co-contraction is mentioned in the literature $(28,29)$ as a mechanism that can promote increased joint stability in response to stimuli towards disequilibrium when attempting to maintain postural control.

\section{Conclusion}

Based on the data in this study, it can be concluded that the competition between motor and cognitive resources significantly affects the muscle activation and co-contraction levels during the gait of young adult women. Hence, we conclude that the accomplishment of dual cognitive tasks during gait can be considered a risk factor for their safe performance. We suggest further studies, involving individuals from populations considered at greater risk for accidents involving pedestrians, like elderly people for example.

\section{References}

1. Hatfield J, Murphy S. The effects of mobile phone use on pedestrian crossing behaviour at signalised unsignalised intersections. Accid Anal Prev. 2007;39(1):197-205.

2. NHTSA. Traffic safety facts annual report. 2004 Final Edition. National Highway Traffic Safety Administration [cited 2014 Sep 14]. Available from: http://tinyurl.com/ hopa7jd.

3. Araújo MM, Diniz LFM, Rocha FL. Impulsividade e acidentes de trânsito. Rev Psiquiatr Clin. 2009;36(2):60-8. 
4. Micheletto TMGP. 0 risco do idoso pedestre nas vias urbanas. CET, Notas Técnicas da Companhia de Engenharia de Tráfego - São Paulo. 2011 [cited 2014 Jul 22]. Available from: http://tinyurl.com/zjp3w7r.

5. Instituto de Pesquisa Econômica Aplicada, Associação Nacional de Transportes Públicos. Impactos sociais e econômicos dos acidentes de trânsito nas aglomerações urbanas - Síntese da Pesquisa. Brasília: IPEA/ ANTP; 2003.

6. Ministério da Saúde. [cited 2014 Jul 27]. Available from: http://portalsaude.saude.gov.br.

7. Vieira ER, Lim HH, Brunt D, Hallal CZ, Kinsey L, Errington $\mathrm{L}$, et al. Temporo-spatial gait parameters during street crossing conditions: A comparison between younger and older adults. Gait Posture. 2015;41(2):510-5.

8. Neider MB, McCarley JS, Crowell JA, Kaczmarski H, Kramer AF. Pedestrians, vehicles and cell phones. Accid Anal Prev. 2010;42(2):589-94.

9. Marinho MS, Chaves PM, Tarabal TO. Dupla-tarefa na doença de Parkinson: uma revisão sistemática de ensaios clínicos aleatorizados. Rev Bras Geriatr Gerontol. 2014;17(1):191-9.

10. Maciel MA, Silva ACSM, Cyrillo FN, Santos S, Torriani-Pasin C. Impact of dual task on Parkinson's disease, stroke and ataxia patients' gait: a comparative analysis. Psicol Reflex Crit. 2014;27(2):351-7.

11. Abbud GAC, Li KZH, Demont, RG. Attentional requeriments of walking according to the gait phase and onset of auditory stimuli. Gait Posture. 2009;30(2):227-32.

12. Nordin E, Moe-Nielssen R, Ramnemark A, Lundin-Olsson L. Changes in step-width during dual-task walking predicts falls. Gait Posture. 2010;32(1):92-7.

13. Dingwell JB, Marin LC. Kinematic variability and local dynamic stability of upper body motions when walking at different speeds. J Biomech. 2006;39(3):444-52.

14. Hermens JH, Freriks B, Disselhorst-Klug C, Rau G. Development of recommendations for SEMG sensors and sensor placement procedures. J Electromyogr Kinesiol. 2000;10(5):361-74.

15. Kang HG, Dingwell JB. Separating the effects of age and walking speed on gait variability. Gait Posture. 2008;27(4):572-7.
16. Candotti CT, Loss JF, Begatini D, Soares DP, Rocha EK, Oliveira AR, et al. Co-contraction and economy of triathletes and cyclists at different cadences during cycling motion. J Electromiogr Kinesiol. 2009;19(5):915-21.

17. Woollacott M, Shumway-Cook A. Attentional the control of posture and gait: a review of an emerging area of research. Gait Posture. 2002;16(1):1-14.

18. Beauchet O, Dubost V, Aminian K, Gonthier R, Kressig RW. Dual task related gait changes in the elderly does the type of cognitive task matter? J Mot Behav. 2005;37(4):259-64.

19. Priest AW, Salamon KB, Hollman JH. Age-related differences in dual task walking: a cross sectional study. J Neuroeng Rehabil. 2008;5:29.

20. Adolph KE, Vereijken B, Shrout PE. What changes in infant walking and why. Child Dev. 2003;74(2):475-97.

21. Winter DA. Foot trajectory in human gait: a precise and multifactorial motor control task. Phys Ther. 1992;72(1):45-53.

22. Plummer-Damato P, Altmann LJ, Reilly K. Dual-task effects of spontaneous speech and executive function on gait in aging: exaggerated effects in slow walkers. Gait Posture. 2011;33(2):233-7.

23. Donker SF, Roerdink M, Greven AJ, Beek PJ. Regularity of center of pressure trajectories depends on the amount of attention invested in postural control. Exp Brain Res. 2007;181(1):1-11.

24. Prado JM, Stoffregen TA, Duarte M. Postural sway during dual tasks in young and elderly adults. Gerontology. 2007;53(5):274-81.

25. 25. Kang HG, Lipsitz LA. Stiffness control of balance during quietstanding and dual task in older adults: the MOBILIZE Boston Study. J Neurophysiol. 2010;104(6):3510-7.

26. Hobara H, Inoue K, Muraoka T, Omuro K, Sakamoto M, Kanosue K. Leg stiffness adjustment for a range of hopping frequencies in humans. J Biomech. 2010; 43(3):506-11.

27. Doi T, Asai T, Hirata S, Ando H. Dual-task costs for whole trunk movement during gait. Gait Posture. 2011;33(4):712-4. 
Hallal CZ, Navega MT, Silva JAMG, Spinoso DH, Morcelli MH, Crozara LF, Marques NR.

28. Fonseca ST, Silva PL, Ocarino JM, Guimaraes RB, Oliveira MT, Lage CA. Analyses of dynamic co-contraction level in individuals with anterior cruciate ligament injury. J Electromyogr Kinesiol. 2004;14(2):239-47.

29. Goldberg EJ, Neptune RR. Compensatory strategies during normal walking in response to muscle weakness and increased hip joint stiffness. Gait Posture. 2007;25(3):360-7.

Received in 10/13/2014

Recebido em 13/10/2014

Approved in 05/12/2016

Aprovado em 12/05/2016 